\title{
Occurrence of Mixed Infection of Tick-Borne Haemoparasite of Cattle in Selected Abattoirs in Makurdi Metropolis, Benue State, Nigeria
}

\author{
T. S. Atsuwe, E. U. Amuta, G. N. Imandeh, and E. T. Azua
}

\section{ABSTRACT}

A study on the occurrence of mixed infection of tick-borne haemoparasite of cattle in selected abattoirs in Makurdi Metropolis, Benue State, Nigeria was carried out. Blood sample were collected randomly from a total of 216 cattle slaughtered at abattoir in both dry and wet season at Wurukum abattoir, Wadata abattoir, Modern Market Abattoir, Cattle Market Abattoir North Bank, Cattle Market North Bank and University of Agriculture cattle farm, Makurdi and analyzed using Microscopic method by thin blood film. Horn method was used to determine the age of the examined cattle and the collected data was analyzed using $T$-test, $p$ values at $\leq$ was considered statistically significant. The result showed that the rate of infection was seen to increase progressively in cattle of age 6-7 through age 10-11 with the highest prevalence recorded in age 10-11 in dry season and the lowest percentage of infection recorded in age $2-3$ and cattle of age $0-1$ showed the highest $(27(75.00 \%))$ rate of infection while age $6-7$ showed the lowest rate of infection in wet season. But the difference was not statistically significant (p $<0.05)$. Male cattle recorded a non statistically significant $(\mathrm{p}<0.05)$ higher $(53.13 \%)$ occurrence of infection while female recorded a lower occurrence of $50.0 \%$.

The result of mixed infection revealed the occurrence of Bebesia, Anaplasmamaginal, Anaplasma central and Theileria. $100 \%$ of mixed infection of Bebesia\&Anaplasmamaginal and Anaplasma central and Anaplasmamaginaloccurred in West African Dwarf cattle and Sokoto gudali respectively. There was no occurrence of mixed infection of Theileria and Anaplasma central across all the examined species of cattle. White Fulani recorded mixed infection of Anaplasma central\&Anaplasmamaginal, Bebesia\&Anaplasma central and Bebesia\&Anaplasmamaginal of 4(30.8\%), $\mathbf{4}(30.8 \%)$ and $5(38.5 \%)$ percent respectively.Muturu species did not record any occurrence of mixed infection of tick borne haemoparasite.The result of the study shows that mixed infection of tick-borne haemoparasite infection are very high and common among cattle hence, preferences should be given to inspection of older male cattle and optimal management of all ruminant animals against ticks and tick-borne related infection.

Key word: Tick-Borne; Haemoparasite; Cattle; Mixed infection Bebesia, Anaplasmamaginal, Anaplasma central; TheileriaAbattoirs.

\section{INTRODUCTION}

Tick-borne haemoparasites including Bebesia, Theileria, Anaplaspmasppamong other parasites have been transmitted by ticks. Ticks are widely distributed around the world, especially in warm, humid climate.In all known life cycles, initial infection of tick occurs in midgut epithelial cells and transmission is achieved when ticks feed after parasites have developed and multiplied in their salivary glands [1] .Many factors affect the development and transmission of haemoparasites by ticks, theseinclude age of ticks, artificial temperature, climate or season, tick stage or sex, haemoparasite variation, concurrent infection of ticks with other pathogens, host cell susceptibility, transovarial transmission and effect of haemoparasites on tick biology and
Published Online: April 30, 2021

ISSN: 2684-5199

DOI: $10.24018 /$ ejbio.2021.2.2.181

\section{T. S. Atsuwe*}

Department of Zoology, Federal University of Agriculture Makurdi, Benue State, Nigeria.

(e-mail: $\quad$ atsuweterese@ ${ }^{@ m a i l . c o m ; ~}$ edidiongudo735@yahoo.com)

\section{E. U. Amuta}

Department of Zoology, Federal University of Agriculture Makurdi, Benue State, Nigeria.

G. N. Imandeh

Department of Zoology, Federal University of Agriculture Makurdi, Benue State, Nigeria.

E. T. Azua

Department of Zoology, Federal University of Agriculture Makurdi, Benue State, Nigeria.

*Corresponding author it has been seen to depend on ticks for biological transmission [2].The ticks are unable to transmit parasites immediately after attachment of their mouthparts [3].Infection of vertebrate hosts starts with the attachment and feeding of infected ticks. Cattle which serve as food to man have their products diminishingas a result of tick-borne haemoparasite. Many people attribute this to diseases of cattle. The most striking problem is whether tick-borne haemoparasites are responsible for diminishing meat and viable economic gains that affect man;thus, research is aimed at occurrence of mixed infection of tick-borne haemoparasite ofcattle in selected abattoirs in Makurdi Metropolis, Benue State, Nigeria. 


\section{MATERIALS AND METHODS}

\section{A. Study Area}

Makurdi is one of the Local Government Areas and the state capital of Benue State Nigeria, located in the North Central geopolitical zone (Fig. 1). It is located in the Middle Belt area of Nigeria and shares boundary with Guma, Gwer, Gwer west and Tarka local government areas. The study area comprises of four abattoirs one cattle market and a cattle farm namelyWurukum abattoir, Wadata abattoir, Modern Market Abattoir, Cattle Market Abattoir North Bank, Cattle Market North Bank and University of Agriculture cattle farm, Makurdi.

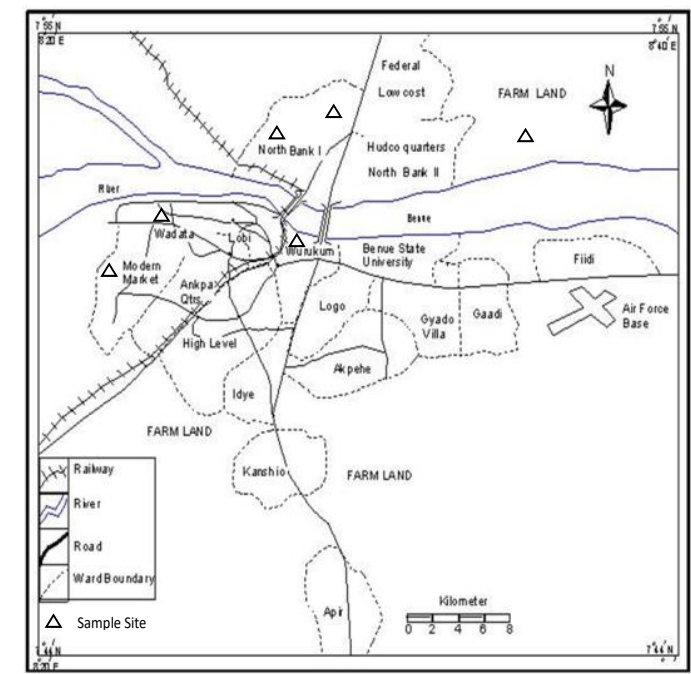

Fig. 1. Map of Makurdi Local Government showing sampling sites ((Ministry of Lands and Survey, Benue State).

\section{B. Sample Size Determination and Sample Selection}

A total of 432 cattle comprising of 216 of cattle slaughtered at abattoir in the dry and wet season were randomly sampled during the period of study. This size was arrived at using Taro - Yamane's formula:

$$
\mathrm{S}=\mathrm{N} / 1+\mathrm{N}(\mathrm{e})^{2}
$$

where

$\mathrm{N}=$ Population studied.

$\mathrm{e}=$ Error margin $(0.05)$.

\section{Determination of Age of Cattle}

Horn method described by World Organization for Animal Health [4] was used to determine the age of the examined cattle. The rings on the horns of cattle were theuseful guides. At ten- or twelve-month-old of cattle, the first ring appears.At thirty- or thirty-two-month-old, the third ring appears and between forty to forty six months old, the fourth ring appears. At fifty four to sixty month, the fifth ring appears and so on. But at the fifth year, the three first rings are indistinguishable and at the eighth year all the rings are distinguished from one another. One complete rind indicates one year [4].

\section{Collection of Blood Sample}

Blood sample was collected at designated areas for the period of three (3) months (December 2018 to February 2019 and May to July 2019) respectively to cover both the dry and raining season. Blood sample was collected from the cattle by jugular vein puncture into EDTA bottles.

The sample was labeled properly, placed in a cooler and transported immediately to University of Agriculture Veterinary Teaching Hospital laboratory, Makurdi where it was examined using thin blood film method.

\section{E. Blood Microscopic Procedure}

The collected blood samples were analyzed using Microscopic method.Thin blood film method as described by Husseinand Singla [5] was used. Briefly, the blood was mix gently with the aid of an applicator stick, few drops of blood was placed at the end of the slide at about $2 \mathrm{~cm}$ to the edge of the slide. A separator was placed in front of the drops of blood and push backward to allow the separator to touch the drop (blood) and allowed to spray all to the sprayer. A firm push was made forward to make the blood dragged behind the separator slide to form a film. The smear was allowed to dry and was labeled for proper identification and was observed under the microscope by X 40 objective [5].

\section{F. Analysis of Data}

Data obtained were analyzed usingt-test and significant differences were considered at $\mathrm{P}$ values $\leq 0.05(\mathrm{p} \leq 0.05)$.

\section{RESULT}

\section{A. Comparison of Cattle with Tick-Borne Haemoparasitesin Relation to the Age and Season}

Table I shows comparison of cattle with tick borne haemoparasites in relation to age and season. In dry season, the rate of infection was seen to increase progressively in cattle of age 6-7 through age 10-11 with the highest prevalence recorded in age 10-11. However, the lowest percentage of infection was recorded in age 2-3 (Fig. 2).

During wet season, cattles of age $0-1$ showed the highest $27(75.00 \%)$ rates of infection while age 6-7 showed the lowest rate of infection. However, the occurrence of infection in wet season was seen to increase progressively from age 4 5 through age 0-1 then further increase steadily from age 6-7 through age 10-11 with age 6-7 recording the lowest 21 $(48.85 \%)$ infection rate.

In comparison, although the highest infection rate 27 (75\%) was recorded in wet season in age $0-1$ and the lowest infection rate recorded in Dry season in age 6-7 (47.82\%) the difference was not statistically significant $(\mathrm{p}<0.05)$.

Across the age groups, age 6-7 was seen to record the lowest rate of infection in the twoseasons.

TABLE I: COMPARISON OF CATTLE WITH TICK BORNE HAEMOPARASITESIN RELATION TO THE AGE AND SEASON

\begin{tabular}{ccccc}
\hline $\begin{array}{c}\text { Age } \\
\text { (Years })\end{array}$ & $\begin{array}{c}\text { Dry season } \\
\text { No. examined } \\
(\%)\end{array}$ & $\begin{array}{c}\text { No. } \\
\text { infected } \\
(\%)\end{array}$ & $\begin{array}{c}\text { Wet season } \\
\text { No. } \\
\text { examined } \\
(\%)\end{array}$ & $\begin{array}{c}\text { No. } \\
\text { infected } \\
(\%)\end{array}$ \\
\hline $0-1$ & $39(18.05)$ & $19(48.71)$ & $36(16.66)$ & $27(75.00)$ \\
$2-3$ & $49(22.68)$ & $23(46.93)$ & $51(23.61)$ & $27(52.94)$ \\
$4-5$ & $47(21.75)$ & $24(51.06)$ & $49(22.68)$ & $25(51.02)$ \\
$6-7$ & $46(21.29)$ & $22(47.82)$ & $43(19.90)$ & $21(48.83)$ \\
$8-9$ & $24(11.11)$ & $15(62.50)$ & $19(8.79)$ & $10(52.63)$ \\
$10-11$ & $11(5.09)$ & $7(63.63)$ & $18(8.33)$ & $10(55.55)$ \\
Total & $216(100)$ & $110(50.92)$ & $216(100)$ & $120(55.55)$ \\
\hline \multicolumn{5}{c}{}
\end{tabular}




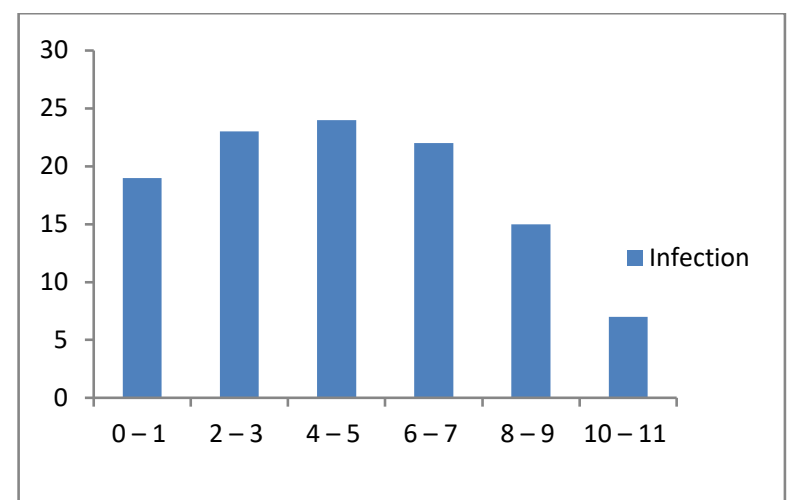

(a)

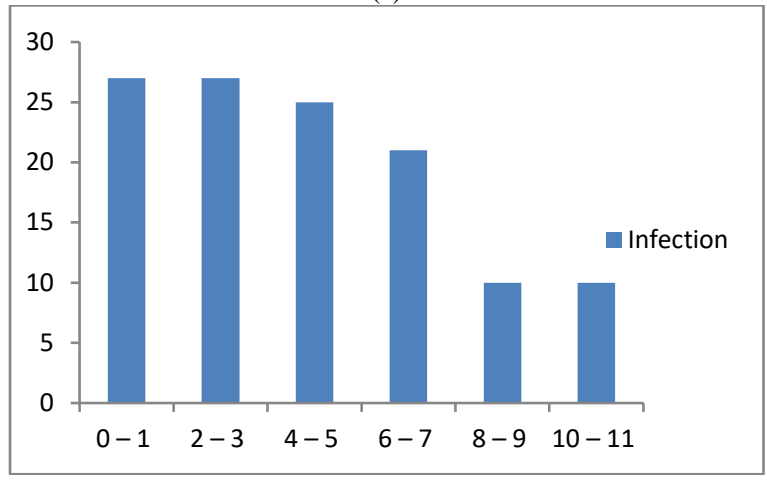

(b)

Fig. 2. Comparison of cattle with tick borne haemoparasites in relation to the age and season: (a) Dry Season Infection; (b)Wet Season Infection.

B. Overall Prevalence of Cattle with Tick-borne Haemoparasite According to Sex

The overall prevalence of cattle with tick-borne haemoparasite according to sex is presented in Table II. Out of a total of 216 cattle examined in dry season, 110(50.93\%) were infected. Male cattle recorded the highest (53.13\%) prevalence of infection while female recorded a low prevalence of $50.0 \%$ (Fig. 3). However, during wet season, despite the high prevalence of infection $(97.22 \%)$ recorded, both male and female cattle showed a closed prevalence rate of infection with 55.71 and 55.48 percent respectively though slightly higher in males. Althoughthe prevalence of infection was high in wet season (Fig. 3), but the difference was not statistically significant $(\mathrm{p}<0.05)$ when compared.

TABLE II: Overall PREvalence of CATtle With Tick Borne HAEMOPARASITEACCORDING TO SEX

\begin{tabular}{ccccc}
\multicolumn{5}{c}{ HAEMOPARASITEACCORDING TO SEX } \\
Sex & $\begin{array}{c}\text { Dry season } \\
\text { No. examined } \\
(\%)\end{array}$ & $\begin{array}{c}\text { No. infected } \\
(\%)\end{array}$ & $\begin{array}{c}\text { Wet season } \\
\text { No. } \\
\text { examined } \\
(\%)\end{array}$ & $\begin{array}{c}\text { No. infected } \\
(\%)\end{array}$ \\
\hline Male & $64(96.63)$ & $34(53.13)$ & $70(32.41)$ & $39(55.71)$ \\
Female & $152(70.37)$ & $76(50.00)$ & $146(67.59)$ & $81(55.48)$ \\
Total & $216(100.0)$ & $110(50.93)$ & $216(100.0)$ & $210(97.22)$ \\
\hline
\end{tabular}

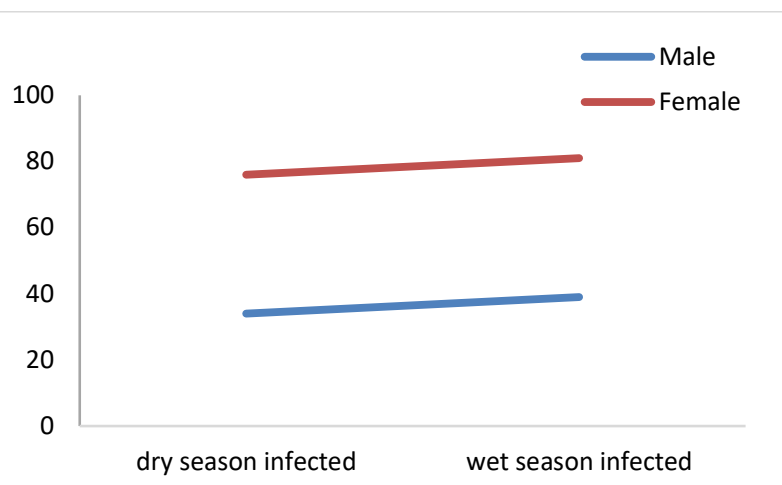

Fig. 3. Graph showing the overall prevalence of cattle with tick borne haemoparasite according to sex.

\section{Occurrence of Mixed Infection in the Studied Cattle for} Tick Borne Haemoparasite

Table III shows the occurrence of mixed infection in various species of cattle infected with tick-borne haemoparasites. In dry season, there was a complete percentage $(100 \%)$ of mixed infection of Bebesia, Anaplasmamaginal and Anaplasma central and Anaplasmamaginal in West African Dwarf cattle and Sokoto gudali respectively.

There was no mixed infection of Theileria and Anaplasma central across all the examined species of cattle. However, White Fulani recorded mixed infection of Anaplasma central\&Anaplasmamaginal, Bebesia\&Anaplasma central and Bebesia\&Anaplasmamaginal of 4(30.8), 4(30.8) and 5(38.5) percent respectively.

Muturu species did not record any occurrence of mixed infection of tick borne haemoparasiteAnaplasma central\&Anaplasmamaginal showed high percentage occurrence of $100 \%$ and $60 \%$ in West African Dwarf cattle and White Fulani respectively. However, Bebesia\&Anaplasma central and Theileria\&Anaplasma central recorded low occurrence $(20.0 \%)$ of mixed infection in white Fulani in raining season. However there was no case of mixed infection Bebesia\&Anaplasmamaginal, Bebesia\&Anaplasma central, and Theileria\&Anaplasma central in West African Dwarf cattle. Bebesia\&Anaplasma central did not record any mixed infection in Sokoto gudali and N'dama. Except white Fulani that recorded $20 \%$ of mixed infection of Theileria and Anaplasma central. All the examined species of cattle did not show any mixed infection of Theileria and Anaplasma central.

TABLE III: OCCURRENCE OF MIXED INFECTION IN THE STUDIED CATTLE FOR TICK BORNE HAEMOPARASITE

\begin{tabular}{|c|c|c|c|c|c|c|c|c|c|c|}
\hline \multirow[b]{2}{*}{ Variety of Cattle } & \multicolumn{5}{|c|}{ Parasite percentage (\%) Dry Season } & \multicolumn{5}{|c|}{ Parasite percentage (\%) Wet Season } \\
\hline & $\begin{array}{c}\text { No } \\
\text { Infected } \\
(\%) \\
\end{array}$ & $\mathrm{AC}+\mathrm{AM}$ & $B+A C$ & $\mathrm{~B}+\mathrm{AM}$ & $\begin{array}{l}\mathrm{T}+ \\
\mathrm{AC}\end{array}$ & $\begin{array}{l}\text { No. Cattle } \\
\text { Examined }\end{array}$ & $\mathrm{AC}+\mathrm{AM}$ & $\mathrm{B}+\mathrm{AC}$ & $\mathrm{B}+\mathrm{AM}$ & $\mathrm{T} / \mathrm{AC}$ \\
\hline White Fulani & $13(65.0)$ & $4(30.8)$ & $4(30.8)$ & $5(38.5)$ & - & $5(29.4)$ & $3(60.0)$ & $1(20.0)$ & - & $1(20.0)$ \\
\hline $\begin{array}{l}\text { West Airican } \\
\text { Dwarf }\end{array}$ & $1(5.0)$ & & & $1(100.0)$ & - & $1(5.9)$ & $1(100.0)$ & & & \\
\hline Sokoto gudali & $2(10.0)$ & $2(100.0)$ & & & - & $4(23.5)$ & $2(50.0)$ & - & $2(50.0)$ & - \\
\hline $\begin{array}{l}\text { Nokoto gudall } \\
\text { N'dama }\end{array}$ & $4(20.0)$ & & $1(25.0)$ & $3(75.0)$ & - & $4(23.5)$ & $2(50.0)$ & - & $2(50.0)$ & - \\
\hline Mutura & - & - & - & - & - & $3(17.6)$ & $1(33.3)$ & $1(33.3)$ & $1(33.3)$ & - \\
\hline Total & $20(100.0)$ & $6(30.0)$ & $5(25.0)$ & $9(45.0)$ & - & $17(100.0)$ & $9(52.9)$ & $2(11.8)$ & $5(29.4)$ & $1(5.9)$ \\
\hline
\end{tabular}




\section{DISCUSSION}

The result of comparison of cattle with tick-borne haemoparasites in relation to age reveals highest prevalence of haemoparasite in cattle of age 10-11 while the least prevalence of infection was recorded in age 2-3.

This is however not surprising as Atsuwe et al. [6] reported a corresponding low prevalence of tick-borne infection in cattle of age 2-3. In their report, they documented that high susceptibility of animals and reduced immunity as a result of stress due to pregnancy, lactation and favourable environmental conditions for survival and proliferation of arthropod vector responsible for their transmission in animal within the age group. There has been report of most cattle having their first pregnancy in age $2-3$ [6].

The low prevalence could be attributed to reduced exposure to the vector borne and immunity acquired by proper veterinary services such as regular application of acaricide.

The high prevalence of infection in age group $0-1$ could be related to transplacental transmission and pre exposure of the calves to the vectors of infection at a very tender age with less immunity to the infection.

Atsuwe et al. [6] recorded a related high prevalence of tick borne haemoparasite infection in calves.

The result of prevalence of infection seen to increase with age specifically from age 8-9 through age 10-11 could be as a result ofprolong exposure of the cattle to tick vectors. Obadiah et al. [7] also obtained a similar result on their previous studies on tick infestation of cattle in three markets in Makurdi North central in cattle $\leq 3$ years and the lowest was seen in older animals [7]. This result is also similar to the report of Asmaa [8] who found that resistance in the animals is built up as animals grow up and older animals become more resistant and adaptable than the younger species irrespective of the farm species.

Male cattle were seen to have high prevalence of infection more than female ones. This result is similar to the reports of Obadiah et al. [7] and Hitcheock [9] who reported that male cattles are more infested with ticks than the female counterparts, this may likely be so, since most of the males in the tropics are manually used for most of the farming activities and move from place to place in fending for themselves and get infested on the course with ticks while the female ones are considered in a restricted area for breeding purpose and therefore are less exposed to tick infestations in the tropics [9].

Soulby reported that larvae of ticks are known to climb blades of grasses and shrubs to attach themselves to passing hosts which are mostly males during grazing [10]. This is however in contrast with studies conducted by Asmaaet al. [8] and Ronny et al. [11] on the prevalence, risk indicators and control options for tick infestation in ruminant in Beni and Epidemiology of ectoparasitic infestation in cattle at Brhuantal Trust area respectively who reported significant higher prevalence of ectoparasitic infestation in females than the male cattle [8], [11].

The result of the study shows that mixed infection of tickborne haemoparasite infection is very high and common among ruminant including cattle. This could be influenced by risk factors such as age and immune status of the host population [12], [13] and it has been reported that distribution and seasonal activity of ticks also contribute to the occurrence of mixed infection [14]. Host species susceptibility to tickborne pathogen also plays a role in determining prevalence of disease[14].

West African dwart cattle and Sokoto gudali show a significant high record of mixed infection in Anaplasma central\&Anaplasmamaginal and Bebesia and Anaplasmamaginal, in contrast this was not detected in Muturu cattle species. Thus, presence of multiple pathogens within an individual host have been reported. Thus, the coinfection may also be associated with poor prognosis, animal husbandry and management. This result is in line with the study conducted by Anderson et al. [12] and disagree with the report by Bilgicet al. [15] on the prevalence of tick-borne haemoparasite in small ruminant [15].

\section{CONCLUSION}

The result of comparison of cattle with tick borne haemoparasites in relation to age reveals highest prevalence of haemoparasite in cattle of age 10-11 while the least prevalence of infection was recorded in age 2-3 and male cattle were seen to have high prevalence of infection more than female ones.The result of the study also shows that mixed infection of tick-borne haemoparasite infection are very high and common among cattle preferences should be given to inspection of older male cattle and optimal management of all ruminant animals against ticks and tickborne related infection.

\section{ACKNOWLEDGEMENT}

The corresponding author acknowledges the Laboratory staff of Federal University of Agriculture, Makurdi, Nigeria. Abigail Atsuwe, Abel Abdulugba and Edidiong Udo.

\section{REFERENCE}

[1] D.E. Sonenshine, Biology of Ticks. vols 1\&2. New York: Oxford University Press. (2014) pp. 45-51.

[2] M. D. Salman, J. Tarrés-Call and A. Estrada-Peña, Ticks and Tickborne Diseases: Geographical Distribution and Control Strategies in the Euro-Asia Region. CABI.(2013) pp.6-12.

[3] L. R. Stephanie,L. Ricky, S. A. Charles and W. Elizabeth, Do Tick Attachment Times Vary between Different Tick-Pathogen Systems.Journal Environments. 4, (3): (2017) 7-13.

[4] World Organization for Animal Health, Manual of diagnostic tests and vaccines for terrestrial animals. Paris: OIE; 2018. Bovine babesiosis. Available http://www.oie.int/fileadmin/Home/eng/Health_standards/tahm/2.04.0 2_BOVINE_BABESIOSIS.pdf.

[5] D. A, Hussein and L. D Singla, Diagnostic approaches for tick-borne haemoparasitic diseases in livestock. J Vet Med Anim Health. 7: (2015) 45-56.

[6] T. S. Atsuwe, E. T. Azua, V. U. Obisike and G. N. Imandeh, Comparative Study on Tick-borne Haemoparasite of Cattle and Goats Slaughtered in Some Abattoirs within Makurdi, Nigeria. Journal of Applied Life Science International; 19(4): (2019) pp 1-6

[7] H. I. Obadiah, I. E. Onah, J. U. Ugochukwu and A. K. Gbinde, Tick Infestation of Cattle in Three Markets in Makurdi, North-Central, Nigeria. American Journal of Entomology. Vol. 1, No. 1, (2017)pp. 610.doi: 10.11648/j.aje. 0101.12.

[8] N.M. Asmaa, M E. Bably and K.A. Shokier,"Studies on prevalence, risk factors and control options for tick infestation in ruminants,"BeniSuef University Journal of Basic and Applied Sciences,vol.3,no.1, (2014) pp.68-73. 
[9] L. F. Hitcheock, "Resistance of the cattle tick, to benzene hexachloride. Journal of Agricultural Research, 29: (1993)41-49.

[10] E. J. L.Soulsby,Helminths Arthropods and Protozoa of Domesticated Animals 7th ed. London, U.K: Bailliere Tindall. (1982) P. 809.

[11] S. A. Rony, M. M. H Mondal, N. Begum, M. A. Islam and S. Affroze, Epidemiology of ectoparasitic infestations in cattle at Bhawal forest area, Gazipur. Bangladesh Journal of Veterinary Medicine, 8 (1): (2010)27-33.

[12] K. Anderson, V.O. Ezenwa and A. E. Jolles, Tick in festation patterns in free ranging African buffalo (Syncercuscaffer):effects of host innate immunity and niche segregation among tick species. Int $J$ Parasitol Parasites Wildl; 2: (2013)1-9.

[13] M. Simuunza, W. Weir, E. Courcier, A. Tait and, B. Shiels, Epidemiological analysis of tick-borne diseases in Zambia.Vet.Parasitol, 175, (2011)331-342.

[14] M. A BakheitandA. A. Latif, The innate resistance of Kenana cattle to tropical theileriosis (Theileriaannulata infection) in the Sudan. Ann NY Acad Sci;969:1 (2002)59-63.

[15] H. B. Bilgic, S. Bakirci, O. Kose, A. H. Unlu, S. Hacilarlioglu, H. Eren, W. Weir and T. Karagenc, Prevalence of tick-borne haemoparasites in small ruminants in Turkey and diagnostic sensitivity of single-PCR and RLB. Parasit Vectors,10: (2017)211. 